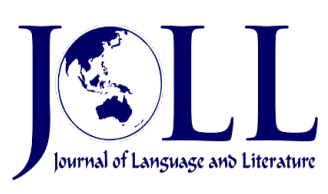

Vol. 21 No. 2, October 2021, pp. 362-375

DOI: 10.24071/joll.v21i2.3190

Available at https://e-journal.usd.ac.id/index.php/JOLL/index

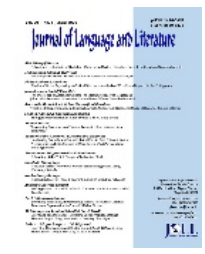

This work is licensed under a Creative Commons Attribution-ShareAlike 4.0 International License.

\title{
Revealing the Intentions of Prince Harry's First Speech after Royal Split: A Systemic Functional Grammar Analysis
}

\author{
Widi Handayani \\ widi.handayani93@gmail.com \\ Graduate Program of English Language Studies, Universitas Sanata Dharma, INDONESIA
}

\begin{abstract}
It is a qualitative research that analyzes the speech delivered by Prince Harry after his royal split. The study is under the study of Systemic Functional Grammar (SFG). It answers the types of processes of the ideational, interpersonal, and textual metafunctions that occurred in the speech. To analyze the data, tables are presented to describe the findings, which are followed by discussions. The result shows that in terms of ideational metafunction, the speaker displays all his concrete actions, including doing charity and meeting many people of his country through the material process. He involves his senses to communicate the language in his mind. It indicates Prince Harry's empathy to the people towards the news of the royal split. The interpersonal metafunction shows that he does take sides on his wife and family. He employs that the media power force creates huge speculations among the citizens. Through this process, he reassures people that his wife is not the cause of the split. The split will not change the commitment he has to serve the country. The personal pronoun 'I' shows that the speaker is the subject matter of the speech. The textual metafunction in the speech indicates that an unmarked theme deploys the idea that it is a declarative speech that functions to give information or clarification. To conclude, the speech is not only a charity speech but also a clarification related to the royal split.
\end{abstract}

Article

information

Received: 11 March 2021

Revised: 28 April 2021

Accepted:

28 May 2021

Keywords: SFG; ideational; interpersonal; textual metafunction

\section{Introduction}

People communicate their thoughts, messages, or ideas through language. Sirbu (2015) clarifies how language is a crucial part of communication since it connects the people in a particular society (p. 405). Through language, they are able to use either oral or written forms. Each of the forms has the same goals, which are transferring and receiving information. 
metafunction. The result shows that Donald Trump uses positive declarative clauses as the first choice and imperative clauses as the second choice. The first personal pronouns such as 'I,' 'we,' and 'you' are frequently used. Darong (2021) studies interpersonal metafunction on Joe Biden's victory speech. The result presents that Joe Biden uses a lot of declarative clauses, modality, and the pronoun 'we.' Cahyani (2017) conducts a study of systemic functional grammar in the students' interpretation of song lyrics. It focuses on transitivity. The result shows the types of processes that aim to make the illustration of the song meanings which are meant by the composers.

This study aims to study the types of processes that occur in speech using the three metafunctions in Systemic Functional Grammar (SFG). The use of the whole field of SFG makes this study different from the previous studies mentioned previously. By that, it will be beneficial to bring new insight to the readers in understanding the three aspects of metafunction, including ideational, interpersonal, and textual metafunction applied in an object. Therefore, this study does not contribute to the development of the theory. However, it helps the readers to enrich their understanding.

\section{Methodology}

It is a qualitative research that specifically studies Systemic Functional Grammar (SFG). The study analyzes the first speech delivered by Prince Harry after Buckingham Palace announced an agreement on his and Meghan's split from the royal duties. The writer takes the transcript of the speech from CNN websites which was published on Monday, January 20, 2020. The title of the transcript is Read Prince Harry's Full Speech after Royal Split, which is written by Jack Guy and Max Foster. In his speech, he clarifies the decision he makes about the split. He also points out that he and his wife, Meghan, do not walk away from all the responsibilities. He states that he and his wife will always serve the Queen and the country. Since it is a charity speech, he also talks about the charity he holds.
Halliday (1988) states that Systemic Functional Grammar is used to study the meaning of the text through the grammatical structure to find the meanings and functions (p. 17). In this case, the researcher studies three metafunctions of SFG, namely ideational, interpersonal, and textual metafunctions, in order to convey the meaning or ideology of the speech. It is suitable for the data since this speech must contain a particular meaning or ideology. Hence, analyzing it will give an understanding of what kind of ideology Prince Harry brings.

The reason for choosing the speech is because it is the very first time Prince Harry gives a speech after his splitting. Of course, everyone wants to hear his clarification. Therefore, the speech is significant. To collect the data, there are several steps done by the writer. First, the writer downloads the script of the speech entitled "Read Prince Harry's full Speech after Royal Split" found on CNN websites. Second, the speech is analyzed based on the categories. Third, the speech is classified into the same categories. Further, to analyze the data, the writer starts with the table showing the occurrence of each of the metafunctions, namely ideational, interpersonal, and textual metafunctions. Then, the writer goes to a deeper analysis by providing some data followed by the discussion. The writer does a peer-review in order to ensure the credibility of the analysis.

\section{Results and Discussion}

The finding shows that in terms of ideational metafunction, the material process frequently occurs, which shows the real actions performed by Prince Harry. In the interpersonal metafunction, modalization shows the idea that Prince Harry performs high commitment of probability which indicates the validation of what is stated in the speech. Meanwhile, in the form of textual metafunction, an unmarked theme occurs frequently to demonstrate that Prince Harry is straightforward in his statements.

Furthermore, the discussion of the findings will be started with the ideational metafunction, interpersonal metafunction, and textual metafunction. 


\section{Ideational Metafunction}

Thompson (2014) argues that ideational metafunction conveys the way people perceive the world through language by communicating their experiences. Besides, it also includes the way they communicate the world through language in their minds (p. 28). Hence, by applying this metafunction in the speech, it is expected to explore the way the language is delivered to communicate the experience. (Ejiofor \& Uchechukwu, 2019, p. 41).

Table 1. Transitivity Process Distribution

\begin{tabular}{|c|c|c|}
\hline Transitivity Process & Frequency & $\%$ \\
\hline Material & 23 & 43.40 \\
\hline Mental & 15 & 28.30 \\
\hline Relational & 5 & 9.40 \\
\hline Circumstantial & 5 & 9.40 \\
\hline Verbal & 3 & 5.70 \\
\hline Existential & 1 & 1.90 \\
\hline Behavioral & 1 & 1.90 \\
\hline TOTAL & 53 & 100 \\
\hline
\end{tabular}

The material and mental processes occurred at 43.40 and $28.30 \%$, respectively. It is followed by the relational and circumstantial process of $9.40 \%$. Each of the processes will be displayed in the discussion below.

\section{Material Process}

The material process is the process when the actor is doing an action. Eggins (2004) reveals that this process is related to actions done by an entity. The actions are usually concrete, noticeable actions. The actions include actors and participants (p. 215). It also deals with the happening process (Wahyudin, 2016 , p. 1). In the speech, there are 23 occurrences of this process.

(1) We both do everything we can to fly the flag and carry out our roles for this country with pride.

(2) The decision that I have made for my wife and I to step back, is not one I made lightly.

(3) What I want to make clear is we're not walking away, and we certainly aren't walking away from you.

(4) It has also been a privilege to meet so many of you, and to feel your excitement for our son Archie, who saw snow for the first time the other day and thought it was bloody brilliant!

Based on the data above, in this process, most of them use the subject pronoun 'I' and 'we.' It indicates that the actions are mostly done by Prince Harry himself and also the collaboration with other people, including his wife and the members of the charity. It shows that Prince Harry really involves in every event or decision. In the first data, the verb do is used to show that the actors really involve in the action of doing the roles to keep the pride of the country. The second data is the verb 'made.' It proves that the decision he makes really influence many lives. The third data is the verb 'walking away.' It is the action that the subject 'we' use to clarify the issue. The fourth data is 'meet.' The action of the meeting is concrete due to the fact that in the charity, the actor really encounters the people of the country.

From the discussion of material process, it is shown that the actions that are manifested in the form of verbs in the speech are concrete since it deals with the real process between the subjects and the objects. Besides, the material process in the speech also indicates clarification, such as in third data, 'what I want to make clear is we're not walking away, and we certainly aren't walking away from you.' The pronoun 'I', which is Prince Harry, clarifies that his family will not run from

\section{Mental Process}

This process refers to the idea that sometimes people communicate, not what they are doing. However, they state what they 
feel or think. It is one of the major processes along with material and relational (Harbi, Jabar, Md Nor, \& Isa, 2019, p. 46). According to Halliday and Matthiessen (2014), there are three types of this process, namely cognition (verbs of thinking, knowing, \& understanding), affection (fearing \& liking), and perception (verbs of hearing and seeing) (p. 118). In other words, mental process refers to the human senses (Pertama, Rukmini, \& Bharati, 2018, p. 421).

(1) I must say that I can only imagine what you may have heard or perhaps read over the last few weeks.

(2) So, I want you to hear the truth from me, as much as I can share -- not as a Prince, or a Duke, but as Harry, the same person that many of you have watched grow up over the last 35 years -- but with a clearer perspective.

(3) The UK is my home and a place that I love. That will never change.

(4) I have grown up feeling support from so many of you, and I watched as you welcomed Meghan with open arms as you saw me find the love and happiness that I had hoped for all my life.

Based on the data above, the three types of mental processes are found in the speech. The verbs 'imagine' and 'hoped' are the type of cognition. It refers to the understanding of imagining and thinking about a certain event. It deals with the work of the brain, which is related to the cognitive system. The other type is affection. It proves with the verbs 'hear' and 'love.' It deals with the feeling of the subject, which mostly is Prince Harry, toward the objects of the clauses such as the news, the wife, and the country. Lastly, it is the type of perception. It shows in the verbs of 'heard,' 'watched,' and 'saw.' It deals more with the sight and hearing instruments. Hence, it can be concluded that in the speech, Prince Harry explores the senses to clarify his information.

\section{Relational-Circumstantial Process}

According to Halliday and Matthiessen (2014), there are a large group of processes in English that do not encode action meanings but encode the states of being. One of the processes is the relational process. It deals with the things that are stated are related to the other things. There are two types of relational processes. Eggins (2004) declares that the types are possessives and circumstantials. Circumstantial refers to the location or place.

(1) Good evening, and thank you for being here for Sentebale, a charity me and Prince Seeiso created back in 2006 to honor my mother's legacy in supporting those effected by HIV and AIDS.

(2) I and all those at Sentebale, be it here in London, Lesotho or Botswana -- will continue the work to make real long-lasting impact for all those that have been left vulnerable.

The data above show the relationalcircumstantial processes are 'being here' and 'be here.' The verbs being and be need to be related to other things so that they cannot stand alone. In other words, they need clarification. In this case, the addition is circumstantial here. It is mentioned previously that 'here' is a location that is considered circumstantial. Hence, 'being here' and 'be here' are employed to clarify a certain place mentioned in the speech. The purpose of saying 'being here' and 'be here' can be meant to include the people in the context of the conversation.

\section{Verbal Process}

This process expresses the way people communicate to express their ideas, feelings, or perceptions toward others. Eggins (2004) clarifies that there are three components in this process. First, it is the Sayer who is responsible for the verbal process. Second, it is the Receiver whom the verbal process is engaged. Lastly, it is the Verbiage which refers to the nominalized statement of the process. There are only three occurrences in this process.

(1) Before I begin, I must say that I can only imagine what you may have heard or perhaps read over the last few weeks.

(2) So ... welcome to Richard's garden -- minus the fountain!

(3) First, may I echo Johnny's words earlier and thank in particular Patricia and 
Richard, and all the teams involved in making tonight so very special and such a success... at least so far... Thank you also for turning up!

Based on the data above, it shows that the verbs are used in the speech just to clarify, thank, and welcome the people. In the first data, the verb 'say' is used to clarify the thing that is still unclear, which is the news of splitting from the royal family. The second data, the verb welcome, is used to show politeness towards other people. In other words, it is part of the manner to greet the guest. The third data, the verb echo, is also used to repeat the words delivered by the previous person in order to sharpen the points.

\section{Interpersonal Metafunction}

Interpersonal deals with the use of language to interact with other people. Specifically, it can be found in both oral and written form (Hulu, 2019, p. 44). It also sees the relationship between the speakers and the interlocutors (Ilham, 2019, p. 33). Thompson (2014) reveals that it can be used to seek out the attitude of the speakers toward what they are talking about (p. 28). Through this metafunction, the meanings of the speech are seen by the language used by the speaker. This metafunction deals with modality, polarity, and personal pronoun.

\section{Modality}

In understanding the modality, there are two types of it, namely modalization and modulation. Further, Thompson (2014) clarifies that modality has two types, namely modalization and modulation. Modalization refers to give information to other users of the language. Meanwhile, modulation focuses on providing goods or services to other language users.

In modality, there are three ways to show speakers' commitment in which they can choose the degree to validate what they are saying. Halliday and Matthiessen (2014) convey it into 3 degrees, high, median, and low (p. 80). Thompson (2014) suggests that in terms of responsibility, explicit subjective, implicit subjective, implicit objective, and explicit objective are often used to show the modalization and modulation (p. 75). To make it clear, the table is employed below.

Table 2. Modality Distribution

\begin{tabular}{|c|c|c|}
\hline Types of modality & Frequency & \% \\
\hline Modalization & 14 & 66.70 \\
\hline Modulation & 7 & 33.30 \\
\hline TOTAL & 21 & 100 \\
\hline
\end{tabular}

\section{Modalization}

Thompson (2014) reveals that modalization refers to give information to other users of the language. In modalization, there are two different areas as well; they are probability as in "the child might be hers" and usuality as in "she often went there" (p. 71).

(1) The UK is my home and a place that I love. That will never change.

(2) I will always have the utmost respect for my grandmother, my commander-in-chief, and I am incredibly grateful to her and the rest of my family, for the support they have shown Meghan and I over the last few months.
(3) But I hope that helps you understand what it had to come to, that I would step my family back from all I have ever known, to take a step forward into what I hope can be a more peaceful life.

(4) First, may I echo Johnny's words earlier and thank in particular Patricia and Richard, and all the teams involved in making tonight so very special and such a success... at least so far... Thank you also for turning up!

The data above show that they all tell the probability by using the modal 'will,' 'may,' and 'would.' The first until the third data indicate the highest level of probability which is reflected in the use of 'will' and 'would.' The 
high level of the commitment is seen as a validation of what is said in the speech. In other words, the commitment to do the action is higher. Meanwhile, the use of modal 'may' indicates that it has low values of probability. In other words, the commitment to doing the action is low. In this case, the action will finish at the moment. It is different between the uses of 'will' or 'would' because it is related to the long-term action such as respecting the family, continuing serving the country, and loving the country. All of the data above are included into implicit subjective in terms of responsibility. It indicates that the subjects and the modal are mentioned inside the clauses or sentences. Thompson (2014) refers it as the way speakers express the point of view in a way that it is their subjective point of view (p. 73).

(1) There's a lot to do, but it's only possible by working together and receiving support from people like yourselves... and like Lewis Capaldi... who has so generously flown here directly from Malaysia, via Dubai -- taking tonight out as a detour on his way to the Grammys in Los Angeles -- where he is nominated for best song.

(2) What I want to make clear is we're not walking away, and we certainly aren't walking away from you. Our hope was to continue serving the Queen, the Commonwealth, and my military associations, but without public funding. Unfortunately, that wasn't possible.

The two statements above are modalization in the form of probabilityHalliday and Matthiessen (2014) mention 3 degrees of probability, namely possibly/probably/certainly. The degrees are equivalent to either yes or no, maybe yes or maybe no (p. 177). Both of the data are included in the degree of possibility. It indicates the lowest degree of probability. In the first data, it shows that there are many things to do and it will be successful if the people work together. If they do not cooperate as a team, then those many things may not finish. The second data shows that the prince with his family wants to serve the country without funding. However, it does not provide conceivably. Hence, the word 'possible' in the second data is more like a dream that cannot be fulfilled. In terms of responsibility, the two statements above are considered implicit objectives. It happens since it conveys the idea that the modality is inside the information and it does not have any speaker. In this case, the focus of the discussions is the idea of many things to do and the inability to serve without public funding.

\section{Modulation}

Thompson (2014) reveals that modulation focuses on providing goods or services to other language users. Besides, in modulation, there are also two areas, namely obligation as in "you should go now" and inclination as in "I'll give you a hand" (p. 71).

(1) Before I begin, I must say that I can only imagine what you may have heard or perhaps read over the last few weeks.

(2) So, I want you to hear the truth from me, as much as I can share -- not as a Prince, or a Duke, but as Harry, the same person that many of you have watched grow up over the last 35 years -- but with a clearer perspective.

(3) We both do everything we can to fly the flag and carry out our roles for this country with pride. Once Meghan and I were married, we were excited, we were hopeful, and we were here to serve.

The data above perform that they form both obligation and inclination. The first data, the modal 'must', indicates the obligation that has to be done. In this case, the obligation is to clarify the issue of the royal split he makes. Since it is the very first speech he has, people are obviously curious about what he will say about the issue. Even though it is not a real clarification speech because it is a charity speech, people still want him to say something related to the issue. In the forms of the values, this modal includes the highest commitment. In terms of responsibility, it is a part of implicit subjective in which the subject is Prince Harry himself, and the modality is inside the action. The other data, the modal 'can', indicates the inclination. It refers to the ability of the people to do the action. In this case, the subject can do the actions such as sharing information, serving the country, and helping other people to live happily. However, in terms of values, the modal is considered as low commitment. 
Besides, the 2 data are also included as implicit subjective which the subject and the modal are clearly mentioned.

\section{Polarity}

The other form of interpersonal metafunction is polarity. Thompson (2014) argues that polarity deals with positive and negative forms. In the negative forms, it is identified by the element ' $n$ ' $t$ ' or 'not.' It also has a specific grammatical structure such as in yes/no interrogative. Besides, polarity is expressed through Mood Adjuncts such as in 'never,' 'hardly,' and 'nothing.' Meanwhile, there are intermediate stages between 'yes' and 'no' such as 'maybe,' 'sometimes,' or 'supposedly.' This is called modal space. It does not intend to say that an expression is positive or negative (p. 68). There are nine clauses or sentences which consist of negative polarity found in the speech.

(1) The decision that I have made for my wife and I to step back, is not one I made lightly.

(2) And I know I haven't always gotten it right, but as far as this goes, there really was no other option.
(3) I've accepted this, knowing that it doesn't change who I am or how committed I am.

The 3 data above are all in the form of declarative forms. Through these polarity clauses or sentences, the subject, Prince Harry, tries to tell that the decision he makes is not a premature decision. He and his wife come up to that conclusion after having a long discussion and consideration. It also conveys that as a prince, he is still a human that often makes mistakes. He reminds people that perhaps his decision is not right for everyone, but it is something he chooses. Hence, people have to appreciate it because there is no other option left. Lastly, he also argues that nothing is able to change him, including his values. It gives a greater understanding that he is still the same Harry with the same commitment.

\section{Personal Pronoun}

Personal pronoun also has a function to this metafunction. It establishes the relation between the speakers and the audience. In the speech, there are many personal pronouns found, such as 'I,' 'we,' 'you,' 'my,' and 'me.'

Table 3. Personal Pronoun Distribution

\begin{tabular}{|l|c|c|}
\hline \multicolumn{1}{|c|}{ Personal Pronouns } & Frequency & \% \\
\hline I & 41 & 35.60 \\
\hline We & 15 & 13.00 \\
\hline You & 15 & 13.00 \\
\hline My & 14 & 12.70 \\
\hline It & 9 & 7.80 \\
\hline Me & 6 & 5.20 \\
\hline Our & 3 & 2.60 \\
\hline Your & 3 & 2.60 \\
\hline Us & 3 & 2.60 \\
\hline They & 2 & 1.70 \\
\hline Her & 1 & 0.80 \\
\hline His & 1 & 0.80 \\
\hline Their & 1 & 0.80 \\
\hline Them & 1 & 0.80 \\
\hline & 115 & 100 \\
\hline
\end{tabular}

Based on the table above, the most frequent of the personal pronoun is $I$, with a total occurrence of 35.60. Later on, it is followed by the pronouns 'we,' 'you,' 'my,' 'it,' and so on. The data in the speech show that in terms of personal pronouns, they consist of subject pronoun, object pronoun, and possessive adjective. Subject pronouns found in the data are 'I,' we,' 'it,' and 'they.'

(1) I also know you've come to know me well enough over all these years to trust that the 
woman I chose as my wife upholds the same values as I do.

(2) Once Meghan and I were married, we were excited, we were hopeful, and we were here to serve.

(3) For those reasons, it brings me great sadness that it has come to this.

(4) I will always have the utmost respect for my grandmother, my commander-in-chief, and I am incredibly grateful to her and the rest of my family, for the support they have shown Meghan and I over the last few months.

Azar (1999) mentions that the subject pronoun is used as the subject of the clauses or sentences (p. 132). In this sense, it can be said that the use of the subject pronoun in the speech is to indicate that the actors really matter in the actions. The highest frequent is the subject pronoun 'I,' so Prince Harry refers to himself as the subject focus of the actions. In other words, it refers to the speaker. Prince Harry is the center of attention. Besides, the use of the subject pronoun 'we' means that he includes other people as one since 'we' can be described as 'I' and the others. It creates emotional effectiveness since it involves other people being in the same position. In other words, it shortens the distance between the speaker and the audience. The pronoun 'it' is used to describe the abstract ideas in the sentence. Further, the pronoun 'they' refers to the subject outside the conversation, which in this case is the family.

The other form of pronoun found in the speech is an object pronoun such as 'you,' 'me,' 'us,' and 'her.' Azar (1999) clarifies that object pronoun is used as the objects of the verbs or objects of prepositions (p. 132).

(1) So, I want you to hear the truth from me, as much as I can share -- not as a Prince, or a Duke, but as Harry, the same person that many of you have watched grow up over the last 35 years -- but with a clearer perspective.

(2) We are taking a leap of faith - thank you for giving me the courage to take this next step.

(3) I first visited Lesotho many years ago, back in 2004, and was shown around by my dear friend Prince Seeiso -- who sadly isn't able to join us this evening.

(4) I will always have the utmost respect for my grandmother, my commander-in-chief, and I am incredibly grateful to her and the rest of my family, for the support they have shown Meghan and I over the last few months.

The data above show that all of them are used to refer to the people he talks to. It creates dialogic communication. It also preserves an intimate relationship between the speaker and the audience. The people mentioned as the object pronoun must be feeling appreciated. The other form of personal pronoun found in the speech is a possessive adjective. Azar (1999) declares that possessive adjectives are directly followed by a noun (p. 132). In this case, the possessive adjectives found are 'my' and 'his.'

(1) I first visited Lesotho many years ago, back in 2004, and was shown around by my dear friend Prince Seeiso -- who sadly isn't able to join us this evening.

(2) I will continue to be the same man who holds his country dear and dedicates his life to supporting the causes, charities and military communities that are so important to me.

The use of the possessive adjective above is to show the possessiveness he has, which in this case are friend and country. It shows that he really means what he has.

\section{Textual Metafunction}

Textual metafunction deals with the organization of the language (Efransyah, 2018, p. 85). The first analysis on this metafunction is started with the types of theme, which is followed by the types of mood and the types of Theme.

\section{Types of theme}

There are two types of theme in this metafunction, namely unmarked and marked theme. 
Table 4. Types of Theme Distribution

\begin{tabular}{|c|c|c|}
\hline Types of theme & Frequency & \% \\
\hline Unmarked & 27 & 55.10 \\
\hline Marked TOTAL & 22 & 44.90 \\
\hline \multicolumn{2}{|c|}{ TOT } & 100 \\
\hline
\end{tabular}

Based on the table above, it clearly shows that the unmarked theme is the highest occurrence of the theme, $55.10 \%$. Meanwhile, the marked theme is in the second-highest of the theme, $44.90 \%$. Each of the themes will be presented below.

\section{Unmarked Theme}

An unmarked theme is indicated by a subject at the beginning of the sentence. Thompson (2014) reveals that an unmarked theme is found in the declarative clauses. It happens because it straightforwardly identifies the clauses or sentences (p. 148). There are 27 occurrences of this theme. Some of them are presented below.

(1) I have grown up feeling support from so many of you, and I watched as you welcomed Meghan with open arms as you saw me find the love and happiness that I had hoped for all my life.

(2) We both do everything we can to fly the flag and carry out our roles for this country with pride.

(3) You've looked out for me for so long, but the media is a powerful force, and my hope is one day our collective support for each other can be more powerful because this is so much bigger than just us.

(4) The decision that I have made for my wife and I to step back, is not one I made lightly.

The data presented above show that all of them are straightforwardly employ the messages directly regarding the subject 'I,' 'we,' 'you,' and 'the decision.' All of them are in the form of declarative since the purpose is to give the information to the audience. Besides, the use of different subjects such as 'I' and 'we' makes the organization of the language is more interesting. It happens because ' $\mathrm{I}$ ' is a singular subject while 'we' is plural which includes the subject 'I' inside.

\section{Marked Theme}

The marked theme is identified with any initial functional elements. It can be a conjunction, finite, or anything in the initial of the clauses or sentences. Thompson (2014) mentions that this type of theme is unusual enough to draw attention to them since their occurrence is when contextual reasons overrule the unmarked as the choice of the subject (p. 149). There are 22 occurrences of this theme.

(1) Before I begin, I must say that I can only imagine what you may have heard or perhaps read over the last few weeks.

(2) So, I want you to hear the truth from me, as much as I can share -- not as a Prince, or a Duke, but as Harry, the same person that many of you have watched grow up over the last 35 years -- but with a clearer perspective.

(3) And this role has taught me more about what is right and just than I could have ever imagined.

(4) First, may I echo Johnny's words earlier and thank in particular Patricia and Richard, and all the teams involved in making tonight so very special and such a success... at least so far... Thank you also for turning up!

Based on the data above, it shows that the initial positions of the clauses or sentences are not subjects. However, most of them are conjunction such as 'before,' 'so,' 'and,' and 'first.' The use of these themes makes the clauses or sentences varied. It happens because it does not always start with a subject in the initial position. Besides, since it is a speech, it is pretty normal to use conjunction as the initial position of the clauses or sentences. It occurs because when a person does a speech, $\mathrm{s} /$ he does not always follow the script. Hence, conjunction is often used to connect with the other clauses or sentences. 


\section{Types of Mood}

In terms of mood, there are three types of mood which are declarative, imperative, and interrogative. However, in this speech, the mood found is only in the form of a declarative.

Table 5. Types of Mood Distribution

\begin{tabular}{|c|c|c|}
\hline Types of mood & Frequency & \% \\
\hline Declarative & 49 & 100 \\
\hline TOTAL & 49 & 100 \\
\hline
\end{tabular}

Based on the data above, it shows that all clauses or sentences in the speech are declarative. Some of the data are presented below.

(1) I'm sure Lewis was the draw factor, but I know you will all be leaving tonight with a better understanding of what we're trying to achieve at Sentebale, and that's what really matters to us.

(2) I first visited Lesotho many years ago, back in 2004, and was shown around by my dear friend Prince Seeiso -- who sadly isn't able to join us this evening.

(3) My work and commitment for this charity, that I founded 14 years ago now, will never falter.

(4) Once Meghan and I were married, we were excited, we were hopeful, and we were here to serve.

The data presented above show that they are all declarative clauses or sentences. It happens because the clauses or sentences only display information such as about a person, visit, or commitment. In the speech, Prince
Harry does not give commands or requests to the people. Besides, he also does not employ questions. Hence, it shows that in the speech, Prince Harry does not show the power dominant to influence other people. Instead, he focuses on telling them about the facts of information. Therefore, it is more like storytelling which still has the goal to influence other people.

\section{Types of Theme}

There are 3 types of Theme, namely experiential, textual, and interpersonal Theme. However, in the speech, based on the analysis, the Theme found is only the textual Theme. The purpose of textual Theme is to connect one clause to another clause. Thompson (2014) clarifies that the elements of textual Theme are conjunctions and conjunctive adjuncts. The conjunctive adjuncts are often considered as a continuation, which refers to a small set called discourse markers (p. 164). In this case, the speech only produces conjunctions as a part of the textual theme.

Table. 6 Textual Theme Distribution

\begin{tabular}{|c|c|c|}
\hline Conjunction & Frequency & $\mathbf{\%}$ \\
\hline Addition (and, or, so) & 66 & 88 \\
\hline Consequence (because, but) & 9 & 12 \\
\hline TOTAL & 75 & 100 \\
\hline
\end{tabular}

Based on the table above, it proves that additional conjunction is the highest number with $88 \%$. Meanwhile, consequential conjunction is only $12 \%$.

\section{Addition}

The additional logical relation in this study is 'and,' 'or,' and 'so.' The function of these conjunctions is to connect one clause to the other clause. 
(1) It has been our privilege to serve you, and we will continue to lead a life of service.

(2) I will continue to be the same man who holds his country dear and dedicates his life to supporting the causes, charities and military communities that are so important to me.

(3) I've accepted this, knowing that it doesn't change who I am or how committed I am.

(4) So, I want you to hear the truth from me, as much as I can share -- not as a Prince, or a Duke, but as Harry, the same person that many of you have watched grow up over the last 35 years -- but with a clearer perspective.

(5) So ... welcome to Richard's garden -- minus the fountain!

Based on the data above, 'and,' 'or' and 'so' are functioned to connect one idea to another idea. Besides, it is used to give detailed information about the topic of the speech. For example, in the first data, Prince Harry mentions that serving the people is an honor, and he connects it to the idea that he and his family will always continue to serve the country. Another example is in the third data. The additional conjunction 'or' is used to describe that every decision he makes will never change him and his commitment to dedicate himself to the country. Besides, the additional conjunction 'so' is functioned to connect or conclude the idea of the clauses. In the fourth data, previously, Prince Harry declares that people might hear news or speculations from the media. Then, the conjunction 'so' is used to request people to hear the explanation from him in order to get a clear clarification. Therefore, the use of additional conjunction is beneficial to give extra information so that the readers are able to get a greater understanding of the knowledge of the topic or the context.

\section{Consequence}

The consequential logical relation in this study are but and because. The function of these conjunctions is to show the contrast idea in one clause to the other clause. The evidence is described below.

(1) So, I want you to hear the truth from me, as much as I can share -- not as a Prince, or a
Duke, but as Harry, the same person that many of you have watched grow up over the last 35 years -- but with a clearer perspective.

(2) Our hope was to continue serving the Queen, the Commonwealth, and my military associations, but without public funding.

(3) You've looked out for me for so long, but the media is a powerful force, and my hope is one day our collective support for each other can be more powerful because this is so much bigger than just us.

Based on the data above, it is seen that the conjunctions are meant to show the contrast among the ideas. In the first data, the conjunction 'but' refers to the idea that people see Harry as the real Harry with a new perspective. In the second data, the conjunction 'but,' again, is used to oppose the idea of one clause to another. In this case, it refers to Prince Harry's hope that he and his family will still serve the country without using public funding. It brings an idea to the people that even after his royal split, he will still serve the country. In short, it shows that the action of serving is still the same. The difference is only in the funding. Finally, the conjunction 'because' is aimed to show the causality. In the third data, it states that the power of media in bringing the news is bigger, so that he hopes that people can support each other since it will be much more powerful when together.

\section{Conclusion}

To conclude, by having an analysis on Halliday's Systemic Functional Grammar (SFG), the speech spoken by Prince Harry has several findings. Firstly, it is illustrated that it is not just a charity speech, but it is a clarification speech about his royal split. He gives the assertion to the people that splitting will not change him. Through interpersonal metafunction, it is seen that he applies a lot of modalization such as 'will' and 'would', which give an affirmation that the speaker has a high commitment to committing to the actions.

Secondly, the clarification is not only promising the people but also clarifying the fact about his wife that she is not the cause of the split. He does take a side on the wife and the family. It is supported by the use of 
pronouns 'I' which describes his determination that the decision is a long consideration. Besides, by performing textual metafunction especially consequence textual theme, he reassures people to believe in him instead of the media.

This study only focuses on the system of grammar analysis only. Hence, it cannot really convey the ideology brought in the speech since it focuses more on the structures. Therefore, future researchers can explore more by combining the theory on Systemic Functional Grammar with other social theories such as theory in psychology or any other theories depend on the context of the objects of the study. In other words, they can conduct a Critical Discourse Analysis to enrich the analysis in this theory.

\section{References}

Azar, B. S. (1999). Understanding and Using English Grammar. New York: Mary Jane Peluso.

Briones, R. R. (2016). Textual Analysis through Systemic Functional Linguistics. Journal of English Language Teaching and Linguistics, 1(2), 109-144.

Cahyani, Y. D. (2017). SFG in the Students' Interpretation of Song Lyrics. Journal of English Language Learning, 1(1), 1-17. Retrieved January 25, 2021, from http://jurnal.umna.ac.id/index.php/JELL /article/view/912.

Darong, H. C. (2021). Interpersonal Function of Joe Biden's Victory Speech (Systemic Functional Linguistics View). Journal of Educational Research and Evaluation, 5(1), 57-66.

Efransyah. (2018). Analyzing Thematic Structure in Indonesian Folktales in English Version: A Systematic Functional Grammar (SFG). Professional Journal of English Education, 1(2), 85-94. Retrieved February 20, 2021, from https://journal.ikipsiliwagi.ac.id/index.p $\mathrm{hp} /$ project/article/view/456/62.
Eggings, S. (2004). An Introduction to Systemic Functional Linguistics (2nd ed). Manchester: Continuum.

Ejiofor, \& Uchechukwu, E. (2019). Investigating Material Clauses in the Igbo Language. Journal of Language and Linguistics(5), 38-55. Retrieved February 20, 2021, from

http://www.jolledu.com.ng/index.php/jo ll/artice/view/66/59.

Guy, J., \& Foster, M. (2020, 1 20). Read Prince Harry's Full Speech after Royal Split. Retrieved 12 20, 2020, from CNN: http://www.google.com/amp/s/amp.cnn .com/cnn/2020/01/20/u/transcriptprince-harry-speech-intl-gbr/index.html.

Halliday, M. (1985). An Introduction to Functional Grammar. London: Edward Arnold Inc.

Halliday, M. K., \& Matthiessen, C. M. (2014). Halliday's Introduction to Functional Grammar. Oxon: Routledge.

Harbi, S., Jabar, M. A., Md Nor, A. N., \& Isa, N. M. (2019). 'Hey, Jude! I Wanna Hold Your Hand': Transitivity Process Analysis on Popular Songs by The Beatles. International Journal of Language Education and Linguistics, 9(1), 45-54. Retrieved February 20, 2020, from http://ijleal.ump.edu.my/.

Hulu, F. (2019). Interpersonal Function in Martin Luther King Jr' Speech. International Journal of Systemic Functional Linguistics, 2(1), 43-46. doi:http://dx.doi.org/10.22225/ijsfl.2.1.9 99.43-46.

Ilham. (2019). Mood and Modality of Interpersonal Meaning in Research Journal Articles. Jurnal Eduscience, 5(1), 30-50. Retrieved January 27, 2021, from https://ejurnal.esaunggul.ac.id/index.ph p/EDU/article/view/2831/2414.

Kadir, S. (2017). The Implication Analysis of Interpersonal Metafunction in Donald Trump's Victory Speech. Al-Gasaq, 1-19.

Koussouhon, L., \& Dossoumou, A. (2015). Exploring Ideational Metafunction in Helon Habila's Oil on Water: A Reevaluation and Redefinition of African Women's Personality and Identity through Literature. International Journal of Applied Linguistics, 4(5), 129-136. doi:10.7575/aiac.ijalel.v.4n.5p.129. 
Pertama, T., Rukmini, D., \& Bharati, D. A. (2018). Implementation of Three Metfunctions in Verbal Language and Visual Image of Students' Textbook. English Education Journal, 8(4), 418-431. Retrieved January 27, 2021, from http://journal.unnes.ac.id/sju/index.php /eej.

Pradiptha, W. A., Purwati, T., \& Hadiati, C. (2020). Reflection of Ideology: A Critical Discourse Analysis of Donald Trump's Declaration Speech of Jerusalem as Capital City of Israel. Journal of English Studies, 1(1), 22-34.

Rahayu, S. H., \& Efransyah. (2020). Transitivity in the Tenth Grade Students' Recount Texts. Professional Journal of English Education, 3(3), 401-407. Retrieved January 30, 2021, from https://journal.ikipsiliwangi.ac.id/index. $\mathrm{php} /$ project/article/view/456/62.

Sirbu, A. (2015). The Significance of Language as a Tool of Communication. "Mircea cel Batran" Naval Academy Scentific Bulletin, 18(2), 405-406.

Thompson, G. (2014). Introducing Functional Grammar. New York: Routledge.

Umiyati, M. (2019). Textual Metafunction in Donald Trump's Speech “Reognizing Jerusalem as Israel's Capital". International Journal of Systemic Functional Linguistics, 2(2), 55-60. Retrieved January 25, 2021, from https://ejournal.warmadewa.ac.id/index. php/ijsfl.

Wahyudin, A. Y. (2016). An Analysis of Process Type Used in News Item. Teknosastik, 16(1), 1-8. doi:10.33365/ts.v14i1.79.

Yang, H. (2017). The Interpersonal Metafunction Analysis of Barack Obama's Inaugural Address. International Journal of Languages, Literature, and Linguistics, 3(1), 27-31.

doi:10.1817/ijill.2017.3.1.105. 